Hrastinski kolleger med erfaring innen nettutdanning komme til orde med refleksjoner som knytter teori til praksis.

Nätbaserad utbildning er ingen tungvekter, verken innholdsmessig eller i fysisk utforming, men det er i grunnen greit. Dette er en populærvitenskapelig introduksjon til nettbasert utdanning, verken mer eller mindre. Hrastinski evner å gi en engasjert innføring i emnet, og den som vil vite mer, kan bruke boken som utgangspunkt for videre fordypning og ikke minst utforske nettet og prøve seg frem på egen hånd.

Det medisinske fakultet, Fakultetsdivisjon Ullevål Universitetet i Oslo

\section{Globalt perspektiv på selvmordsforskning}

Wasserman D, Wasserman C, red. Oxford textbook of suicidology and suicide prevention

912 s, tab, ill. Oxford: Oxford University Press, 2009. Pris GBP 75

ISBN 978-0-19-857005-9

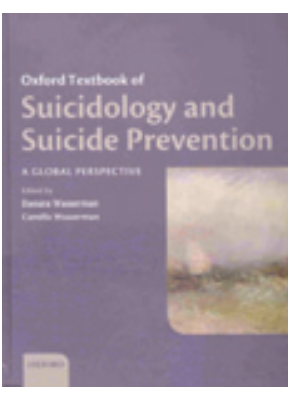

Dette er et nytt referanseverk i suicidologi. Det omhandler forekomst av, årsaker til og behandling og forebygging av selvmordsatferd alt $i$ et globalt perspektiv. Det vil si at alle kontinenter er representert, til tross for at hovedtyngden av forskning og rapportering av mortalitetsdata hittil har kommet fra Europa, Australia og Nord-Amerika. Målgruppen er forskere innen feltet, men også klinikere og samfunnsmedisinere.

Det er 15 deler, som igjen er delt inn i underkapitler. Hovedtyngden er viet selvmordsforekomst, bakgrunn og behandling, med utgangspunkt i forskningsdata. Den siste delen består av eksempler på selvmordsforebyggende strategier fra ulike land og er mer deskriptiv.

Dette er en ambisiøs utgivelse, både i omfang og tilnærming. Det er et stort antall bidragsytere, men en god redaksjonell jobb gjør at det er lite overlapping mellom kapitlene. Det er gjennomgående imponerende oppdatert kunnskap og referansetilfang. Det finnes derimot unntak, slik som et kapittel om restriksjoner i tilgangen på medikamenter hvor referanser til Hawton og medarbeideres studier på pakningsstørrelse og forskrivningspraksis savnes.

Styrken er det globale perspektivet. Til tross for at dødelighetsdata ikke rapporteres systematisk fra mange land i f.eks. Afrika og det er gjort lite forskning her, er det nyttig med en kunnskapsoppsummering som viser status på feltet - særlig siden den systematiske gjennomgangen kontinent for kontinent avdekker at $i$ absolutte tall er det flest selvmord i folkerike land som Kina, selv om populasjonsbasert statistikk og rater mangler. I flere land i Afrika og LatinAmerika har man antatt at selvmordsraten har vært lav, men forskning i de senere år har avdekket økende rater, spesielt blant unge.

Redaktørene har valgt en tilnærming der hver enkelt problemstilling har fătt ett kapittel av omtrent samme omfang. Dette innebærer at Major psychiatric disorders in suicide and suicide attempters har fătt like stor plass som Representations of suicide in cinema. For å få oversikt over problemstillinger i feltet fungerer dette overraskende greit. Som utgangspunkt for videre forskning blir de store temaer psykisk lidelse, farmakologisk behandling og kognitiv behandling nok for summarisk beskrevet.

Som helhet gir Oxford textbook of suicidology and suicide prevention en god oppsummering av forskningsstatus når det gjelder selvmord og selvmordsforebyggende arbeid. Andre bøker innenfor feltet har gått mer i dybden når det gjelder hvordan man kan forstå suicidalatferd og behandling av dette. Men forskere og andre interesserte får her en god oversikt over et sammensatt forskningsfelt med internasjonale utfordringer.

\section{Mari Asphjell Bjørnaas}

Akuttmedisinsk avdeling

Oslo universitetssykehus, Ullevål

\section{Liten, men viktig bok om hypertensjon}

Kahan T, Nyström F, red.

Hypertoni och 24-timmars mätning av blodtryck

101 s, tab, ill. Lund: Studentlitteratur, 2009 Pris SEK 165

ISBN 978-91-44-04797-3

Ifølge Verdens helseorganisasjon er høyt blodtrykk den viktigste årsak til død i verden. Om politikere liker det eller ikketilstanden affiserer omtrent halvparten av alle voksne i Europa. Ifølge en artikkel i The Lancet vil over $90 \%$ av alle europeere på et eller annet tidspunkt i løpet av sitt liv få diagnosen hypertensjon (1). All god litteratur fra dette feltet ønskes derfor velkommen. Denne lille utgivelsen om høyt blodtrykk er rettet mot legestudenter og ferdige leger. Den inneholder et velskrevet kapittel om moderne utredning og behandling av hypertensjon, et relativt kort kapittel om forskjellige metoder for blodtrykksmåling samt et utdypende kapittel om bruk av 24timers blodtrykksmåling. Det er flere gode illustrasjoner og tabeller, som for det meste er hentet fra internasjonal litteratur. Forfatterne er begge rutinerte klinikere og av Sveriges mest kjente hypertensjonsforskere. Hypertoni och 24-timmars mätning av blodtryck er lettlest og nyttig, men man spør seg om det er verdt å betale 165 svenske kroner for noe som lettvint og gratis kan lastes ned fra nettet (se f.eks.www@eshonline.org).

\section{Sverre E. Kjeldsen}

Hjertemedisink avdeling

Oslo Universitetssykehus, Ullevål

\section{Litteratur \\ 1. Hypertension: uncontrolled and conquering the world. Lancet 2007: 370: 539.}

\section{Et spørsmål om liv og lære?}

Klepp KI, Aarø LE, red.

Ungdom, livsstil og helsefremmende arbeid 390 s, tab, ill. Oslo: Gyldendal Akademisk, 2009 Pris NOK 425

ISBN 978-82-05-32552-4

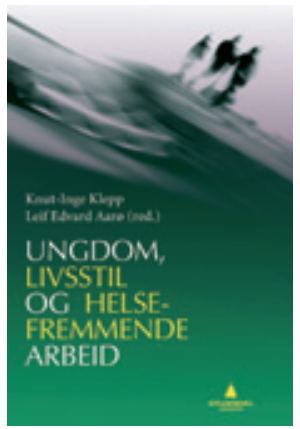

Innledningsvis lover redaktørene at denne utgaven av boken er en fullstendig revisjon. Ungdom, livsstil og helsefremmende arbeid første gang ble utgitt i 1991. Den er i mange henseende enestående i Norge - en rekke felter innen helsefremmende arbeid blant ungdom behandles, og flere av forfatterne er sentrale forskere innen det felt de skriver om.

Den er tradisjonelt komponert. Allerede i første kapittel beskrives den virkning livsstil, risikoatferd og mestring kan ha på helsen, og på den måten settes resten av stoffet inn i en ramme. Samtidig blir ulike virkemidler for å fremme god helse drøftet. Drøftelsene er underbygd av anerkjente teorier og har referanser til forskning. Relevante temaer som røyking og bruk av alkohol er brukt til å illustrere teoriene.

Tannhelse, ernæring og kosthold, overvekt og fedme, spiseforstyrrelser, seksualitet og seksualatferd, ulykker og skader, minoritetsungdom og skeiv ungdom er temaer. Skole, mobbing og skolehelsetjenestens muligheter har også fått grundig omtale. Kunnskap om og strategier for å fremme unges helse formidles greit. 